\title{
Thermal degradation kinetics of rutin and total phenolic compounds in rosehip (Rosa canina $L$.) nectar
}

\author{
Kuşburnu (Rosa canina $L_{\text {. }}$ ) nektarında rutin ve toplam fenolik bileşiklerin \\ ısıl parçalanma kinetiği
}

\author{
Çetin KADAKAL ${ }^{1}$ (iD), Tolga DUMAN² (iD) \\ 1,2Food Engineering Department, Engineering Faculty, Pamukkale University, Denizli \\ ckadakal@pau.edu.tr, tduman10@posta.pau.edu.tr
}

Received/Geliș Tarihi: 09.02.2017, Accepted/Kabul Tarihi: 31.05.2017

doi: $10.5505 /$ pajes.2017.03779

*Corresponding author/Yazıșılan Yazar Research Article/Araștırma Makalesi

\begin{abstract}
In this research it is attempted to determine the loss of rutin and total phenolic compounds in rosehip nectar with the heating periods $(0,5,10$ 15,20 and $30 \mathrm{~min}$ ) at temperatures ranging from 70 to $95{ }^{\circ} \mathrm{C}$. Spectrophotometric and liquid chromatographic (HPLC) methods were used to determine the concentrations of total phenolic compounds and rutin, respectively. Thermal degradations of TPC and rutin in rosehip nectar were fitted to a first-order reaction kinetic model. Arrhenius relationship was used in order to describe the temperature dependence of reaction. Activation energies for rutin and TPC between 70 to $95{ }^{\circ} \mathrm{C}$ were found to be 46.90 and $35.72 \mathrm{~J} / \mathrm{mol}$, respectively.
\end{abstract}

Keywords: Degradation kinetics, HPLC, Phenolic, Rosehip nectar, Rutin, Water- soluble vitamin

\section{Introduction}

The main native land of Rosehip (Rosa canina $L$ ), belongs to the plant family of Rosaceae, is West Asia-North Europe [1],[2] and Middle East-North-East Anatolia of Turkiye [3].

Rosehip is a good source of some biologically active compounds. The main importance of rosehip is its high composition of vitamin $\mathrm{C}$ and rutin (vitamin $\mathrm{P}$ ) and high content of pectins, fatty acids, sugars, organic acids, phenolic components, lycopene, carotene with activity of vitamin A, group B vitamins and vitamin $\mathrm{K}$, tannins, carotenoids, minerals (particularly K and P) macro- and microelements [4]-[8].

Rosehip is the fruit with the highest level of vitamin C, as well as an important source of rutin (vitamin P). The other important food sources of rutin is buckwheat, onion, lemon, apple, orange, and grapefruit [9] and tea [10]. Rutin, a compound of the flavonoid class as flavanoid glycoside, consist of quercetin and the disaccharide rutinose [11]-[12] and has antioxidant [13], antiinflammatory [14], neuroprotective [12],[15], antihyperglycaemic [16] and antimicrobial [17] activities.

Phenolic compounds are separated into two groups as phenolic acids and flavonoids. Flavonoids are polyphenolic antioxidants found in natural herbal teas, fruits and vegetables [18]. Some of the phenolic compounds are effective in the formation of the flavor components of fruits and vegetables, particularly in the formation of two important flavors such as bitterness and sourness in the mouth. Some of them provide the colors of fruits and vegetables in yellow, yellow-brown, red-blue tones [19],[20]. Phenolics have antioxidant, antimutagenic and anticarcinogenic effects and are capable of altering gene
Öz

Bu çalıșmanın amacl, kuşburnu nektarının 70 ile $95{ }^{\circ} \mathrm{C}$ sıcaklık aralığında periyodik olarak farklı süreyle $(0,5,10,15,20$ ve $30 \mathrm{dk}$.) Isl işleme tabi tutulmasına bağlı olarak rutin ve toplam fenolik bileşik içeriğinde meydana gelen değissimin belirlenmesidir. Kuşburnu nektarının rutin içeriği sıvı kromatografisi (HPLC) ve toplam fenolik madde miktarı spektrofotometrik yöntemle analiz edilmiștir. Isll ișlem sırasında, kușburnu nektarında ısıl ișlem uygulamasına bağlı olarak rutin ve TFB içeriğinin bozunması birinci dereceden kinetik modele uymuștur. Reaksiyonun sıcaklık bağımlılığı Arrhenius ilișkisi ile tanımlanmıștır. Rutin ve TFB içeriğinin 70 ile $95{ }^{\circ} \mathrm{C}$ sıcaklık aralığındaki aktivasyon enerjileri sirasiyla 46.90 ve $35.72 \mathrm{~J} / \mathrm{mol}$ olarak bulunmuştur.

Anahtar kelimeler: Parçalanma kinetiği, HPLC, Fenolik, Kușburnu nektarı, Rutin, Suda çözünen vitamin expression [21],[22]. Rosehips are very rich in phenolics [23]. The total phenolic content (TPC) of Rosa canina has been found to be $96 \mathrm{mg}$ gallic acid equivalent/g dry weight [22].

Several analytical techniques such as spectrophotometric [24] and liquid chromatographic [25]-[29] have been tested for rutin analysis. HPLC is the preferential method for rutin separation in terms of rapid, accurate and sensitive quantitative determination.

While maintaining quality factors in maximum level in safe food production, kinetic models for thermal treatments are necessary in food production designs [30]. Thus, technological control and prediction of quality in foods can be achieved by kinetic modeling of food changes [31]. As far as we know, no report was published about the HPLC determination of rutin content of rosehip pulp or nectar and thermal degradation of rutin and TPC of rosehip nectar. In this study it was aimed:

a) To determine the rutin and TPC changes during thermal treatments $\left(70,80,90\right.$ and $\left.95^{\circ} \mathrm{C}\right)$,

b) To determine the degradation kinetics of rutin and TPC in rosehip nectar with different thermal processing $(0,5,10,15,20,25$ and 30 minutes $)$ at temperatures between 70 and $95{ }^{\circ} \mathrm{C}$,

c) To define degradation reactions with the determination of kinetic parameters (reaction rate constant, order of reaction, activation energy, $\mathrm{Q}_{10}$, half-life). 


\section{Material and methods}

\section{$2.1 \quad$ Fruits}

The dried rosehip fruits (Rosa canina $L$ ) were provided from a well-Established local factory (Gümüssu Food Co., Gümüshane) in eastern Black Sea Region of Turkey. Nearly 250 kilograms of dried fruits were transferred in sacks to the laboratory of Pamukkale University, Denizli, Turkey and processed for rosehip nectar.

\subsection{Production of rosehip nectar}

The rosehip fruit, which is washed in under tap water in a clean container, is ground by a fruit grinder. During the milling of the fruit, about 1-1.5 times the water weight of the fruit is added [32]. After mashing at $70^{\circ} \mathrm{C}$ for 30 minutes, rosehip pulp was obtained by passing through screens of 1.6 and $0.4 \mathrm{~mm}$ pore size. According to Turkish Food Codex, fruit nectar is defined as an unfermented product prepared with addition of water, sugar or honey into fruit pulp or puree. The pulp was processed to nectar by sugar, citric acid and water supplement up to $12-13$ brix with minimum $40 \%$ puree and maximum $10 \%$ sugar. So, the acidity and water-soluble matter of the pulp were adjusted to $5.5 \mathrm{~g} / \mathrm{l}$ and $16 \%$ to obtain rosehip nectar, respectively. After cooling in an ice-water bath at 20-25 ${ }^{\circ} \mathrm{C}$, the nectar was transferred to pyrex tubes (75x10 mm ID) for the treatment of thermal degradation and stored at $4{ }^{\circ} \mathrm{C}$ until thermal processing.

\subsection{Thermal treatment}

The thermal treatments of rutin and TPC were studied at 70,80, 90 and $95^{\circ} \mathrm{C}$. Rosehip nectar samples of $25 \mathrm{~mL}$ were heated in pyrex tubes ( $75 \times 10 \mathrm{~mm}$ ID) placed in a thermostatic water bath (Model 3047, Kottermann, Hänigsen/Germany). Time application was started after the temperatures of the samples measured by thermocouple reached the desired temperature. It took less than 8 minutes to reach the desired temperature in all heating treatments. The caps of the tubes were tightly closed and placed in a thermostatic water bath. After removal of nectar samples at regular periods they were quickly cooled under running water. Rutin and TPC were determined using three test tubes removed from the thermostatic water bath every 5 minute. All results were performed in triplicate and the reaction rate constants of each temperature were calculated in triplicate.

\subsection{Selection of temperatures and heating periods}

Depending on the heating time, about $70{ }^{\circ} \mathrm{C}$ is the lowest value used in industrial-scale production of rosehip nectar. On the other hand, in the conventional production method used in Turkey, the bottle nectar is left in boiling water for about 20-30 minutes in open type boilers. Thus, the temperature of rosehip nectar in the bottle reaches about $95^{\circ} \mathrm{C}$.

\section{$2.5 \quad$ Analysis of rutin}

\subsubsection{Equipment}

A liquid chromatography (Shimadzu corporation, Kyoto, Japan) system consisting of a UV-VIS DAD detector, (Model SPD-M10 AVP, Shimadzu), a column oven (Model CTO-10ASVP, Shimadzu), a quadruple liquid chromatography pump (Model LC-10AT-VP, Shimadzu), a degasser (Model DGU 14A, Shimadzu) and a Shimadzu Software Program was used for the analysis. Additionally, a reversed-phase Discovery $\mathrm{C}_{18}$ column (15 cm x $4.6 \mathrm{~mm}$ ID, $5 \mu \mathrm{m}$ particle size) (Cat. No:
504955) from SUPELCO (Bellefonte, PA, USA) was used in the HPLC system.

\subsection{Reagents}

HPLC grade methanol and extra pure potassium dihydrogen phosphate were supplied from Merck (Darmstadt, Germany). Doubly distilled and deionized water was used in the experiments. Analytical-reagent grade standard of rutin was obtained from Sigma Chemical Company (DeisenhofenGermany). Five different concentrations of rutin standard prepared in mobile phase were used for the preparation of calibration curve. All solutions were stored in dark glass flasks in refrigeration against the negative effects of light. Thus, five point calibration curve, covering the range of 5-250 ppm with the correlation coefficients of 0.999 based on the concentration (mg/L) versus peak area (mAU), was prepared by using stockstandard solutions of rutin. Triplicate injections with each standard solution were made for the preparation of calibration curve.

\subsection{Sample preparation (Solid phase extraction=SPE)}

Many components of rosehip cause chromatographic interferences with rutin in HPLC. Therefore, a SPE with Sep-Pak C18 (500 mg) cartridges that let the separation of rutin and remove most of the interfering components were used in sample preparation. A $25 \mathrm{~g}$ of deionized water were added into $5 \mathrm{~g}$ rosehip nectar (Dilution factor, $\mathrm{F}=6$ ). Following the homogenization of the mixture using a homogenizer at medium speed for $1 \mathrm{~min}$, homogenized mixture was centrifuged for 10 min at $14 \times 10^{3} \mathrm{rpm}$ (Model 2-16, Sigma Bioblock Scientific). The extraction of rutin was carried out with some modification of SPE method [33]. A $10 \mathrm{ml}$ methanol and $10 \mathrm{ml}$ water adjusted at $\mathrm{pH} 4.2$ was used in flushing for the activation of stationary phase. Following the activation of stationary phase, both homogenized and centrifuged rosehip nectar $(10 \mathrm{~mL})$ was loaded. The $\mathrm{pH}$ value of the acidified water was prepared by the addition of $0.005 \mathrm{M} \mathrm{HCl}$ solution drop by drop until a predetermined $\mathrm{pH}$ value was reached. The sample was eluted with water ( $5 \mathrm{~mL}, \mathrm{pH} 4.2$ ) then $10 \mathrm{ml}$ methanole at a flow rate of $1 \mathrm{ml} / \mathrm{min}$. Following the elution, eluents were collected in a bottle and evaporated to dryness. After the dissolving of the residue in mobile phase, aliquot of $20 \mu \mathrm{l}$, filtered with $0.45 \mu \mathrm{m}$ pore size filters (Schleicher-Schuell, Darmstadt-Germany), was injected into the HPLC column for the quantitative determination of rutin.

\subsection{Methods}

A photodiode array detector set at $204 \mathrm{~nm}$ for the determination of rutin was used to achieve the column eluate monitoring. Following the degassing of mobile phase by sonication, filtered through a $0.45 \mu \mathrm{m}$ filter prior to use. The elution solvents, used in the HPLC analysis, were $0.1 \mathrm{~mol} / \mathrm{L}$ potassium dihydrogen phosphate (pH: 7) and methanol (90:10) with the flow rate of $0.7 \mathrm{ml} / \mathrm{min}$. The column was operated at $25{ }^{\circ} \mathrm{C}$. Thus, chromatographic data on the peaks were integrated up to $12 \mathrm{~min}$. Integrated area for sample and the corresponding standard was used for the calculation of the rutin concentration.

\subsection{Recovery of rutin}

Rosehip nectar samples containing known amount of rutin was spiked with the two addition levels of standard rutin for the determination of recovery. For this purpose, six injections were carried out for each addition level. 


\subsection{Calculation of kinetic parameters}

A general equation for thermal degradation kinetics can be written as given below: [34].

$$
-\frac{d[C]}{d t}=k[C]^{m}
$$

Where,

$$
\begin{array}{ll}
\mathrm{C} & : \text { quantitative amount }(\mathrm{mg} / \mathrm{L}) \text { of the constituent, } \\
\mathrm{k} & : \text { reaction rate constant, } \\
\mathrm{m} & : \text { order of the reaction. }
\end{array}
$$

After the integration of Eq. (1), the equation for first order kinetics can be written as:

$$
\ln \left(\frac{[C]_{t}}{[C]_{0}}\right)=-k t
$$

Where, $[\mathrm{C}] 0$ and $[\mathrm{C}] \mathrm{t}$ are the initial and residual vitamin, respectively. $\mathrm{k}$ is the reaction rate constant $(1 / \mathrm{min})$ and $\mathrm{t}$ represents the time (min.).

Temperature dependence of rutin and TPC was described by the Arrhenius equation 3 , given below:

$$
k=k_{0} \times e^{-E_{a} / R T}
$$

Where, $\mathrm{k}$ is the rate constant (milligrams rutin or TPC per min), $\mathrm{k}_{0}$ the frequency factor (per min), $E_{a}$ the activation energy (kilojoules per mole), $T$ the absolute temperature $(\mathrm{K})$, and $R$ is the universal gas constant $\left(8.314 \times 10^{-3} \mathrm{~kJ} / \mathrm{mol} \mathrm{K}\right)$ :

Quotient indicator $\left(Q_{10}\right)$ is another technique for the expression of the dependence of reaction rate on temperature and calculated with the equation 4 :

$$
Q_{10}=\left(\frac{k_{2}}{k_{1}}\right)^{\frac{10}{T_{2}-T_{1}}}
$$

Where, $T$ is temperature in $C, \mathrm{k}_{1}$ and $\mathrm{k}_{2}$ are the rate constants of rutin and/or TPC degradation at temperatures T1 and T2, respectively.

The time required degrading $50 \%$ of original concentrations of rutin and TPC was calculated using the equation 5 given below:

$$
t_{1 / 2}=0.693 / k
$$

Where, $k$ is the reaction rate constant (per min).

\subsection{Analysis of TPC}

TPC of rosehip nectar was determined by using the Folin Ciocalteu spectrophotometric method. For this purpose, 40, 80, 120, 160 and 200 ppm concentrations of gallic acid solutions were prepared. With $75 \mathrm{ml}$ of distilled water, $1 \mathrm{ml}$ of sample was mixed in a volumetric flask $(100 \mathrm{ml})$ followed by the addition of $5 \mathrm{ml}$ Folin-Ciocalteu and let to stand for $3 \mathrm{~min}$. Then, saturated sodium carbonate solution $(10 \mathrm{~mL}, 20 \%)$ was added and shaken well again. The volumetric flask was then filled with distilled water up to $100 \mathrm{ml}$. A UV/VIS spectrophotometer (T80, PG Instruments, UK) was used for reading the absorbance of the resultant solution at $720 \mathrm{~nm}$ after $1 \mathrm{~h}$ standing in a dark place. Quantification was based on the standard curve of gallic acid ( 0 $200 \mathrm{mg} / \mathrm{L}$ ) which was dissolved in deionized water and expressed as mg gallic acid equivalent (GAE) per liter.

\subsection{Further determinations}

AOAC [35] method was used for the analysis of total solid (\%), water soluble solid (Bx), pH and total acidity (dry tartaric acid). The amounts of total sugars in the rosehip nectar were determined according to the Lane-Eynon method [36].

\subsection{Statistical analysis}

SAS ${ }^{\circledR}$ software [37] was used for the statistical analysis of all data. Data means were compared using least significant difference test, when analysis of variance (ANOVA) showed a significant effect $(\mathrm{P}<0.05)$.

\section{Results and discussion}

In the world literature, the number of studies on rutin values and rutin changes of foodstuffs is limited and studies are mostly in the field of medicine. However, as far as we know, there have been no degradation kinetic studies on the rutin and TPC and HPLC determination of rutin in rosehip nectar. This work is important to complete lack of the world literature.

As known, each component has a wavelength that gives maximum absorbance such as rutin. So, the detection wavelength was set at max absorption wavelength of rutin for higher sensitivity. As shown in Figure 1, rutin is separated well and a good separation achieved in 12 min. Compound identification was achieved by the comparison of its retention time value and UV spectra with the standard reference compound of data bank. Two unknown peaks were also detected in the chromatogram. However, no interference between the rutin and unknown peaks were observed.

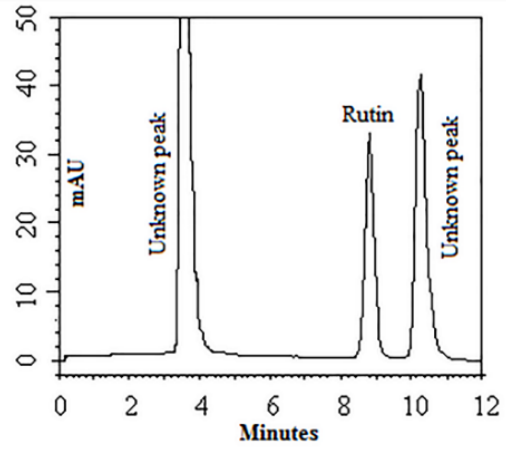

Figure 1: Separation of rutin by isocratic elution with potassium dihydrogen phosphate (pH: 7) and methanol (90:10).

\subsection{Analytical characteristic of the HPLC method}

\subsubsection{Linearity, Detection limit, Recovery and precision}

Linearity of standard curve, detection limit, precision and recovery of method for determination of rutin in rosehip nectar is shown in Table 1 . An $\mathrm{R}$ value of 0.999 was obtained for rutin. Coefficient of determination $\left(\mathrm{r}^{2}\right)$ was determined as $99.82 \%$. The detection limit for rutin, based on S/N (signal/noise) of 3 [38], was $0.5 \mathrm{ppm}$. The method reliability was confirmed by two recovery experiments. Standard addition procedure was used for the recovery test. Thus, 30 and $50 \mathrm{mg} / \mathrm{L}$ concentrations of rutin standards were added to the samples. In each addition level, six determinations were realized. The average percentage recovery of rutin in rosehip nectar was determined as $102.3 \pm 0.54 \%$. The method precision was evaluated using the same reagents and apparatus under the same experimental conditions with six determinations of the same rosehip nectar sample. In addition, intra- and inter-day tests were applied for the calculation of precision and the results were expressed as relative standard deviation (RSD, \%). The evidence of good precision for HPLC is low RSD value that determined (2.20\%) in our study. In addition, the low RSD value also shows non-variability of the data. 


\subsection{Characteristics of rosehip nectar samples used}

The characteristics of the rosehip nectar used in the study are as follows: $13.9 \pm 0.04 \%$ total solid, $12.75 \pm 0.35 \mathrm{Bx}$ soluble solids, $3.85 \pm 0.07 \mathrm{pH}$ value, $0.35 \pm 0.01 \%$ total acidity and $12.29 \pm 0.02 \%$ total sugar, $268.4 \pm 4.0 \mathrm{mg} / \mathrm{L}$ rutin and $2294 \pm 0.1 \mathrm{mg} \mathrm{GAE} / \mathrm{L} \mathrm{TPC}$. Soluble solids, $\mathrm{pH}$ and TPC of rosehip nectar (glass-bottled) were reported as $16.2 \mathrm{Bx}, 3.50$ and $1967 \mathrm{mg}$ catechin per liter, respectively (Duru et al. 2012).

\subsection{Thermal degradation of TPC and rutin in rosehip nectar}

Thermal stability of TPC and rutin in rosehip nectar were studied at $70,80,90$ and $95^{\circ} \mathrm{C}$. As seen from Figure 2 and 3, the degradations of TPC and rutin are fitted to first-order kinetic model. As the heating temperature and time increased, the degradation of TPC and rutin increased. A linear relation, which shows the plot for TPC and rutin in rosehip nectar, correlates to first-order degradation kinetics with the correlation coefficient above 0.98 for all cases. It is pointed out that statistical differences between zero or first-order reactions may be insignificant [34] On the other hand, there are no published data on the thermal degradation of TPC and rutin in rosehip nectar. So, we didn't compare our results with the literature.

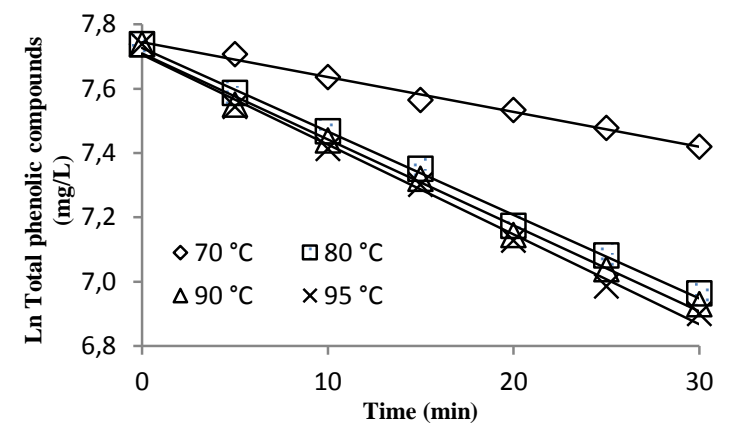

Figure 2: First order kinetic of TPC thermal degradation in rosehip nectar at four different temperatures.

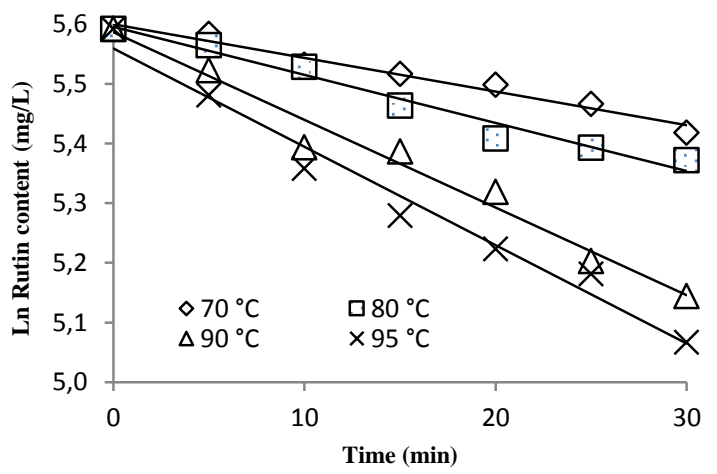

Figure 3: First order kinetic of rutin thermal degradation in rosehip nectar at four different temperatures.

Table 2 shows the degradation rate constants (k) and half-lives $\left(\mathrm{t}_{1 / 2}\right)$ for TPC and rutin in rosehip nectar. The linear inclination of the plot of $\ln (\mathrm{C} / \mathrm{C} 0)$ against $t$ was used in order to estimate the degradation rate constant. The rate constants of TPC and rutin increased with the increment of temperature. This result suggests that degradations of TPC and rutin are temperaturedependent. TPC indicated the minimum degradation rate constant followed by rutin, suggesting that rutin is less inclined to degradation than TPC. The rate constant of rutin increased slightly with the increment of temperature from 70 to $80^{\circ} \mathrm{C}$ and
90 to $95^{\circ} \mathrm{C}$, but increased significantly from 80 to $90{ }^{\circ} \mathrm{C}$. The results imply that rutin was very unstable at $95^{\circ} \mathrm{C}$ as approved by higher $k$ values resulting a fast degradation. In contrast, the rate constant of TPC increased significantly from 70 to $80^{\circ} \mathrm{C}$ and increased slightly with the increament of temperature from $80 \quad$ to $\quad 90 \quad{ }^{\circ} \mathrm{C} \quad$ and 90 to $95{ }^{\circ} \mathrm{C}$., The $k$ values of rutin and TPC varied between $5.6 \times 10^{-3}-16.5 \times 10^{-3}$ and $10.8 \times 10^{-3}-28 \times 10^{-3}$ at temperatures between 70 and $95{ }^{\circ} \mathrm{C}$, respectively (Table 1). Consequently, degradation of TPC and rutin increased with the increment of heating temperature and time.

As shown in Table 1, with the increment of temperature the half-life values $\left(t_{1 / 2}\right)$ for rutin and TPC decreased. According to the $t_{1 / 2}$ values, rutin and TPC degrade faster at higher temperatures. Rutin showed the highest $t_{1 / 2}$ values when compared with the TPC at the same temperatures. This result indicates the higher thermal stability of rutin at the same temperatures in rosehip nectar when compared with the TPC. If the logarithm of the rate constants vs reciprocal of absolute temperatures process to a linear coordinate system, the slope of the linear curve gives the value of Ea/R (Figure 4). Activation energies for rutin and TPC degradation in rosehip nectar were different at temperature between $70-95^{\circ} \mathrm{C}$. Rutin showed the highest activation energy, followed by TPC. These results suggest that rutin is more stable to thermal degradation in rosehip nectar compared to TPC. The high activation energy of a reaction indicates that this reaction is very sensitive to temperature change. Therefore, rutin and TPC of rosehip nectar are more susceptible to thermal degradation at $95{ }^{\circ} \mathrm{C}$ than $70{ }^{\circ} \mathrm{C}$. The activation energies were calculated as 35.72 and $46.90 \mathrm{~J} / \mathrm{mol}$ for the degradations of TPC and rutin, respectively.

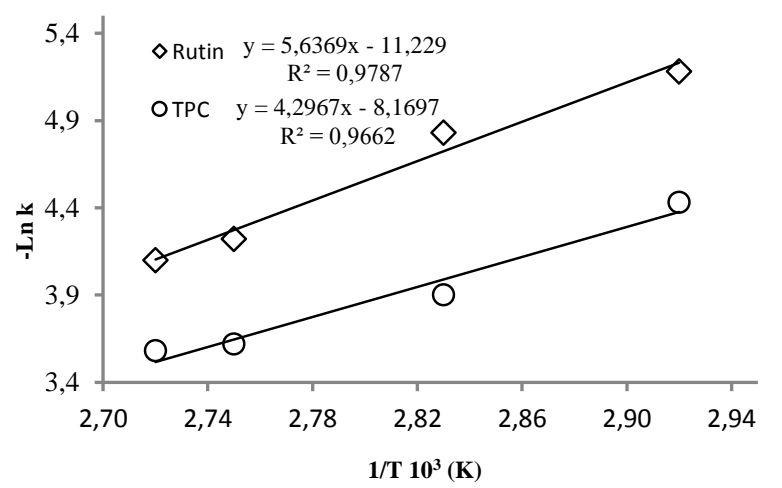

Figure 4: Arrhenius plots for degradation of TPC and rutin in rosehip nectar during heating.

For that reason, the calculated $\mathrm{Q}_{10}$ values of rutin and TPC are compared to the literature reported $Q_{10}$ values of other sources. Table 2 shows the $Q_{10}$ values of rutin and TPC in rosehip nectar between the temperatures of 70 and $95^{\circ} \mathrm{C}$. The $\mathrm{Q}_{10}$ values, for increases of each $10{ }^{\circ} \mathrm{C}$, were different in rosehip nectar at temperatures ranging from 70 to $95^{\circ} \mathrm{C}$. The highest $Q_{10}$ values for rutin and TPC are obtained within the ranges of 80 to $90{ }^{\circ} \mathrm{C}$ and 70 to $80{ }^{\circ} \mathrm{C}$, respectively. This result point out that the thermal degradation of rutin and TPC was highyl affected with the temperatures in the ranges of 80 to $90^{\circ} \mathrm{C}$ and 70 to $80{ }^{\circ} \mathrm{C}$, respectively. In the range of 90 to $95^{\circ} \mathrm{C}$, the $\mathrm{Q}_{10}$ values of rutin and TPC are the same, indicating that within this range the degradation kinetics are very few affected by the temperature change. 
Table 1: Linearity of standard curve and detection limit, recovery and precision of method for determination of rutin in rosehip nectar.

\begin{tabular}{|c|c|c|c|c|c|c|c|c|}
\hline \multirow{2}{*}{ Vitamin } & \multirow{2}{*}{$\begin{array}{l}\text { Linear } \\
\text { range } \\
\text { (mg/L) }\end{array}$} & \multirow{2}{*}{$\mathrm{R}$} & \multirow{2}{*}{$r^{2}$} & \multirow{2}{*}{$\begin{array}{l}\text { Detection limit } \\
\quad(\mathrm{mg} / \mathrm{L})\end{array}$} & \multirow{2}{*}{$\begin{array}{l}\text { Initial content } \\
\quad(\mathrm{mg} / \mathrm{L})\end{array}$} & \multirow{2}{*}{$\begin{array}{l}\text { Content } \\
\text { after } \\
\text { addition } \\
(\mathrm{mg} / \mathrm{L})^{\mathrm{a}}\end{array}$} & $\begin{array}{c}\text { Recovery } \\
(\%)\end{array}$ & Precision \\
\hline & & & & & & & $\begin{array}{l}\text { Mean } \\
\text { S.D }\end{array}$ & $\begin{array}{c}\text { R.S.D. } \\
(\%)\end{array}$ \\
\hline Rutin & $5.0-250.0$ & 0.999 & 99.82 & 0.5 & $248.6 \pm 0.9$ & $299.8 \pm 0.13$ & $102.3 \pm 0.54$ & 2.20 \\
\hline
\end{tabular}

Table 2: Effect of temperature on the activation energy (Ea), reaction rate constant ( $\mathrm{k}$ ), Q10 and half-life (t1/2) values of rutin and and TPC.

\begin{tabular}{|c|c|c|c|c|c|c|c|}
\hline \multirow{2}{*}{ Vitamin } & \multirow{2}{*}{$\mathrm{T}\left({ }^{\circ} \mathrm{C}\right)$} & \multirow{2}{*}{$\begin{array}{c}\mathrm{k} 10^{3} \\
(1 / \mathrm{min})\end{array}$} & \multirow{2}{*}{$\mathrm{t}_{1 / 2}(\min )$} & \multicolumn{3}{|c|}{$\mathrm{Q}_{10}$} & \multirow[t]{2}{*}{$\mathrm{E}_{\mathrm{a}}(\mathrm{J} / \mathrm{mol})$} \\
\hline & & & & $70-80^{\circ} \mathrm{C}$ & $80-90^{\circ} \mathrm{C}$ & $90-95^{\circ} \mathrm{C}$ & \\
\hline \multirow{4}{*}{ Rutin } & 70 & 5.6 & 123.75 & \multirow{4}{*}{1.43} & \multirow{4}{*}{1.84} & \multirow{4}{*}{1.26} & \multirow{4}{*}{46.90} \\
\hline & 80 & 8.0 & 86.63 & & & & \\
\hline & 90 & 14.7 & 47.14 & & & & \\
\hline & 95 & 16.5 & 42.00 & & & & \\
\hline \multirow{5}{*}{$\begin{array}{c}\text { Total } \\
\text { Phenolic } \\
\text { Compounds }\end{array}$} & 70 & 10.8 & 64.16 & \multirow{5}{*}{2.4} & \multirow{5}{*}{1.03} & \multirow{5}{*}{1.10} & \multirow{5}{*}{35.72} \\
\hline & 80 & 25.9 & & & & & \\
\hline & & & 26.76 & & & & \\
\hline & 90 & 26.7 & 25.96 & & & & \\
\hline & 95 & 28.0 & 24.75 & & & & \\
\hline
\end{tabular}

\section{Conclusion}

Thermal degradation of rutin and TPC of rosehip nectar heated at various temperatures were evaluated first time in the world. Degradation of rutin and TPC followed firs-order kinetics. As the temperature and heating time increased, degradation rate of examined compounds increased. The best temperature for the less reduction of rutin and TPC of rosehip nectar for long term heating of rosehip nectar was $70{ }^{\circ} \mathrm{C}$. The rosehip nectar producing industry may benefit from the results of this study when controlling the amount of rutin and TPC in production process. The consequences of this research will assist the rosehip nectar industry in minimum loss of rutin and TPC. These parameters are important quality criteria for rosehip nectar. Therefore, knowing the degradation kinetics of rutin and TPC is important. In addition, there is no study on the thermal degradation of rutin and TPC of rosehip nectar. Therefore, this study will shed light on future studies

\section{Acknowledgement}

This work was supported by research Grant 2011FBE078 from Research Project Fund (BAP) of Pamukkale University. The authors thank the Gumussu Food AS (Yuksel DEMIR) for providing the rosehip.

\section{References}

[1] Yamankaradeniz R. "Farklı olum aşamalarındaki kuşburnu (Rosa sp.)'nun fiziksel ve kimyasal nitelikleri". Glda, 8(4), 151-156, 1983.

[2] Artik N, Ekși A. "Bazı yabani meyvelerin (Kuşburnu, Yemişen, Alıç, Yaban Mersini, Kızamık) kimyasal bileşimi üzerine araştırma". Gıda Sanayi, 2(14), 33-34, 1988.

[3] Davis PH. Flora of Turkey and the East Aegean Islands. $1^{\text {st }}$ ed. Edinburgh, Scotland, Edinburgh University Press, 1972.
[4] Türkben C, Uylaser V, Incedayi B, Çelikkol I. "Effects of different maturity periods and processes on nutritional components of rose hip (Rosa canina L.)". Journal of Food Agriculture and Environment, 8(1), 26-30, 2010.

[5] Tuer DF, Russel P. The nutrition and Health Encylopedia. $1^{\text {st }}$ ed. New York, USA, Von Nostrand Reinhold, 1989.

[6] Demir F, Özcan M. "Chemical and technological properties of rose (Rosa canina L.) fruits grown wild in Turkey". Journal Food Engineering, 47(4), 330-336, 2001.

[7] Roman I, Stănilă A, Stănilă S. "Bioactive compounds and antioxidant activity of Rosa canina L. biotypes from spontaneous flora of Transylvania". Chemistry Central Journal, 7(73), 1-10. 2013.

[8] Abaci ZT, Zarifikhosroshahi M, Kafkas E, Sevindik E. "Chemical composition, volatiles and antioxidant activity of rosa iberica Stev. Hips". Acta Scientiarum Polonorum Hortorum Cultus, 15(1), 41-54. 2016.

[9] Attia TZ. "Simultaneous determination of rutin and ascorbic acid mixture in their pure forms and combined dosage form". Spectrochimica Acta Part A Molecular and Biomolecular Spectroscopy, 169, 82-86, 2016.

[10] Kuntic V, Peji N, Ivkovic B, Vujic Z, Ilic K, Mici S, Vukojevic V. "Isocratic RP-HPLC method for rutin determination in solid oral dosage forms". Journal of Pharmaceutical and Biomedical Analysis, 43(2), 718-721, 2007.

[11] Kicel A, Owczarek A, Michel P, Skalicka-Woźniak K, Kiss A, Olszewska M. "Application of HPCCC, UHPLC-PDA-ESIMS3 and HPLC-PDA methods for rapid, one-step preparative separation and quantification of rutin in forsythia flowers". Industrial Crops and Products, 76, 86-94, 2015.

[12] Yıldırım S, Kadıoğlu A, Sağlam A, Yaşa A. "Determination of phenolic acids and rutin in Heliotropium thermophilum by high-performance liquid chromatography with photodiode array detection". Instrumentation Science \& Technology, 45(1), 35-48, 2017. 
[13] Korkmaz, A.; Kolankaya, D. "Protective Effect of Rutin on the ischemia/reperfusion induced damage in rat kidney". Journal Surgery Research, 164(2), 309-315, 2010.

[14] Lee W, Ku SK, Bae JS. "Barrier protective effects of rutin in lps-induced inflammation in vitro and in vivo". Food and Chemical Toxicology, 50(9), 3048-3055, 2012.

[15] Tongjaroenbuangam W, Ruksee N, Chantiratikul P, Pakdeenarong N, Kongbuntad W, Govitrapong P. "Neuroprotective effects of quercetin, rutin and okra (Abelmoschus esculentus Linn.) in dexamethasone-treated mice". Neurochemistry International, 59(5), 677-685, 2011.

[16] Kamalakkannan N, Prince PSM. "Antihyperglycaemic and antioxidant effect of rutin, a polyphenolic flavonoid, in streptozotocin-induced diabetic wistar rats". Basic and Clinical Pharmacology and Toxicology, 98(1), 97-103, 2006.

[17] Singh M, Govindarajan R, Rawat AKS, Khare PB. "Antimicrobial flavonoid rutin from Pteris vittata $\mathrm{L}$. against pathogenic gastrointestinal microflora". American Fern Journal, 98(2), 98-103, 2008.

[18] Nizamlığlu MN, Nas S. "Meyve ve sebzelerde bulunan fenolik bileşikler; yapıları ve önemleri". Gıda Teknolojileri Elektronik Dergisi, 5(1), 20-35, 2010.

[19] Gökalp HY, Nas S, Certel M. Biyokimya-I. Temel Yapilar ve Kavramlar. 3 baskı. Denizli, Türkiye, Pamukkale Üniversitesi Mühendislik Fakültesi Matbaası, 2002.

[20] Cvejic JH, Krstonosic MA, Bursac M, Miljic U. Polyphenols. Editors: Galanakis CM. Nutraceutical and Functional Food Components: Effects of Innovative Processing Techniques, 203-238, London, UK, Elsevier Academic Press, 2017.

[21] Nakamura Y, Watanabe S, Miyake N, Osawa T. "Dihydrochalcones: evaluation as novel radical scavenging antioxidants". Journal of Agricultural and Food Chemistry, 51(11), 3309-3312, 2003.

[22] Ercisli S. "Chemical composition of fruits in some rose (Rosa spp.) species". Food Chemistry, 104(4), 1379-1384, 2007.

[23] Olsson ME, Andersson S, Werlemark G, Uggla M, Gustavsson KE. "Caretonoids and phenolics in rosehips". Acta Horticulturae, 690, 249-253, 2005.

[24] Kuntic V, MalesÏev D, Radovic Z, Vukojevic V. "Spectrophotometric investigation of the complexing reaction between rutin and titanyloxalate anion in 50\% ethanol". Monatshefte für Chemie, 131(7), 769-777, 2000.

[25] Daigle DJ, Conkerton EJ. "Analysis of flavonoids by HPLC: an update". Journal of Liquid Chromatography, 11(2), 309-325, 1988.
[26] Leite JPV, Rastrelli L, Romussi G, Oliveira AB, Vilegas JHY, Vilegas W, Pizza C. "Isolation and HPLC Quantitative Analysis of Flavonoid Glycosides from Brazilian Beverages (Maytenus ilicifolia and M. aquifolium)". Journal of Agricultural and Food Chemistry, 49(8), 3796-3801, 2001.

[27] Li WK, Fitzloff JF. "High performance liquid chromatographic analysis of St. John's wort with photodiode array detection". Journal of Chromatography. B: Biomedical Sciences and Applications, 765(1), 99-105, 2001.

[28] Menghinello P, Cucchiarini L, Palma F, Agostini D, Dachà M, Stocchi V. "Simultaneous analysis of Flavonoid aglycones in natural products using an RP-HPLC method". Journal of Liquid Chromatography \& Related Technologies, 22(19), 3007-3018, 1999.

[29] Pang N, Malike D, Liu H. "Simultaneous determination of main bioactive components in rosa multiflora thunb. and their fragmentation study by LCMS". Chromatographia, 70(7-8), 1253-257, 2009.

[30] Avila IMLB, Silva CLM. "Modelling kinetics of thermal degradation of color in peach puree". Journal Food Engineering, 39(2), 161-166, 1999.

[31] Van boekel MAJS. Kinetic Modeling of Reactions in Foods. $1^{\text {st }}$ Ed. London, UK, CRC Press, 2008.

[32] Nas S, Gökalp HY. "Kuşburnu ve pestil teknolojisi ve gida değeri". Atatürk Üniversitesi Ziraat Fakültesi Dergisi, 24(2), 142-150, 1993.

[33] Cho CM, Ko JH, Cheong WJ. "Simultaneous determination of water-soluble vitamins excreted in human urine after eating an overdose of vitamin pills by a HPLC method coupled with a solid phase extraction". Talanta, 51(4), 799-806, 2000.

[34] Labuza TP, Riboh D. "Theory and application of Arrhenius kinetics to the prediction of nutrients losses in foods". Food Technology, 36(10), 66-74, 1982.

[35] AOAC. Official Methods of Analysis. 15th ed. Association of Official Analytical Chemists, Washington, DC, USA, 1990.

[36] Cemeroglu B. Meyve ve Sebze İşleme Endüstrisinde Temel Analiz Metotları. 1 baskı. Ankara, Türkiye, Biltav, 1992.

[37] SAS®_ Institute. SAS user's guide. Statistics. Version $5^{\text {th }}$ Ed. Cary, NC, SAS Institute Inc. 1985.

[38] Li, HB, Chen F. "Determination of silicate in water by ion exclusion chromatography with conductivity detection". Journal of Chromatography A, 874(1), 143-147, 2000. 